\title{
ANALISIS MODEL PENDALILAN GOLONGAN HABIB: AMALAN TAWASSUL DENGAN ORANG MATI DAN TAWASSUL DENGAN PERKATAAN MADAD
}

\author{
Nur Adilah Amiruddin dan Fadlan Mohd Othman \\ Jabatan Pengajian al-Quran dan al-Sunnah, Fakulti Pengajian Islam \\ Universiti Kebangsaan Malaysia \\ dila050990@yahoo.com
}

Diterima 29 Agustus 2017 | Direview 12 September 2018 | Diterbitkan 31 Desember 2018

\begin{abstract}
:
Discussions on Tawassul have been done by scholars since antiquity. However, the diversity of beliefs that have emerged lately including the existence of the 'Selawat Perdana' and 'Malam Cinta Rasul' phenomenon that was brought by Habib group causing discussion on this issue to become warm again. Among the expressions introduced by the Habib group in their occasion were al-Madad Ya Rasulullabwhich in that expression includes the practice of Tawassul with the dead and Tawassul with the word Madad.What is more alarming is that the Islamic community is so easy to accept the practices introduced by Habib group because of their position as the descendants of the Prophet. Hence, this paper is produced to re-evaluate the arguments submitted by the Habib group in defending the practice of Tawassul with the dead and with the word of Madad. This study is a qualitative study using case study method where the data collection process is done through content analysis and internet studies. Meanwhile, the data analysis process is done through descriptive, thematic and comparative approaches. The findings show that the arguments posed by some of the Habib's groups against these two issues were not strong and thus the necessity of the practices was also questioned. The results of this study have important implications for the Muslim community to evaluate whether the Tawassul practices highlighted by the Habibians are in accordance with the law or otherwise.
\end{abstract}

Keywords: Habib, Istidlāl, Tawassul, Tawassul with dead, Madad

\begin{abstract}
Abstrak:
Pembicaraan tentang masalah Tawassul telah dilakukan oleh para ulama sejak jaman dahulu. Namun, keragaman keyakinan yang muncul akhirakhir ini termasuk keberadaan fenomena 'Selawat Perdana' dan 'Malam Cinta Rasul' yang dibawa oleh kelompok. Habib menyebabkan diskusi
\end{abstract}


tentang masalah ini menjadi hangat lagi. Di antara ekspresi yang diperkenalkan oleh kelompok. Habib dalam kesempatan mereka adalah alMadad Ya Rasulullah yang dalam ungkapan itu termasuk praktek Tawassul dengan orang mati dan Tawassul dengan kata Madad. Yang lebih mengkhawatirkan adalah babwa komunitas Islam begitu mudah untuk menerima praktik yang diperkenalkan oleb kelompok Habib karena posisinya sebagai keturunan Nabi. Oleh karena itu, makalah ini dibuat untuk mengevaluasi kembali argumen yang diajukan oleh kelompok Habib dalam membela praktik. Tawassul dengan orang mati dan dengan kata Madad. Penelitian ini merupakan penelitian kualitatif dengan menggunakan metode studi kasus dimana proses pengumpulan data dilakukan melalui analisis isi dan studi internet. Sementara itu, proses analisis data dilakukan melalui pendekatan deskriptif, tematik dan komparatif. Temuan menunjukean babwa argumen yang diajukan oleh beberapa kelompok Habib terhadap dua masalah ini tidak kuat dan dengan demikian perlunya praktik. juga dipertanyakan. Hasil penelitian ini memiliki implikasi penting bagi komunitas Muslim untuk. mengevaluasi apakah praktik. Tawassul yang disorot oleb Habibian sesuai dengan bukum atau sebaliknya. Kata kunci: Habib, Istidlall, Tawassul, Tawassul dengan mati, Madad

\section{Pendahuluan}

Tiga jenis Tawassul yang disyariatkan di dalam Islam adalah bertawassul dengan nama-nama serta sifat Allah SWT, bertawassul dengan orang-orang soleh yang masih hidup dan bertawassul dengan amalan soleh yang pernah dilakukan oleh diri sendiri. ${ }^{1}$ Pada hakikatnya, perbincangan mengenai bertawassul dengan orang soleh ini merupakan perbincangan yang telah pun dibincangkan oleh para ulama dengan perbincangan yang begitu panjang lebar. Namun secara ringkasnya, telah bersepakat para ulama tentang keharusan bertawassul dengan orang soleh yang masih hidup berdasarkan dalil-dalil yang kukuh daripada petunjuk al-Quran serta Sunnah baginda SAW ${ }^{2}$. Antaranya kisah yang diceritakan oleh Allah SWT melalui firmanNya di dalam al-Quran mengenai anak Nabi Ya'qūb AS yang meminta agar baginda AS memohonkan keampunan buat mereka kepada Allah SWT:

\footnotetext{
1 'Abdullāh bin 'Abd al-Hamīd Al-Athari, Al-Tawassul Bayna Al-Masyrū' Wa Al-Mamnü', n.d.

2 Muḥammad bin Jamīl Zīnū, "Kayfa Nafham Al-Tawassul.," Rìyadh: Dār Al-Samīè 3 (n.d.).
} 

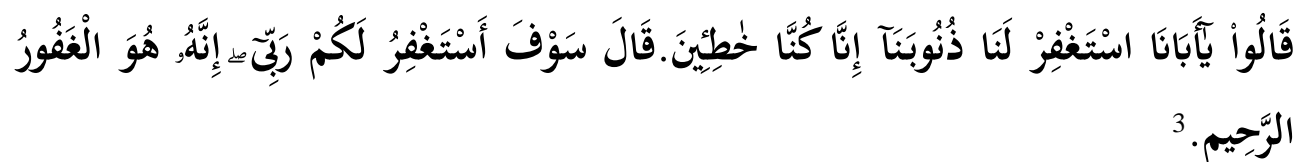

Mereka berkata: "Wabai ayah kami! Mintalah ampun bagi kami akan dosa-dosa kami; sesunggubnya kami adalah orang-orang yang bersalab". Nabi Yaakub berkata: "Aku akan meminta ampun bagi kamu dari Tubanku; sesunggubnya Dia-lah jua Yang Maba Pengampun, lagi Maba Mengasibani".

Ibn Kathīr ketika mentafsirkan ayat tersebut telah menyatakan bahawa anak-anak Nabi Ya'qūb AS memohon keampunan kepada Allah SWT melalui bapa mereka kerana mereka telah melakukan kesalahan terhadap Nabi Yūsuf $\mathrm{AS}^{4}$. Maka, secara tidak langsung dapat difahami melalui ayat tersebut bahawa harusnya mengambil perantaraan orang soleh yang masih hidup untuk meminta sesuatu hajat kepada Allah SWT.

Isu yang terus menjadi persoalan adalah apakah hukum bertawassul dengan orang soleh yang telah meninggal dunia. Sebahagian pihak termasuk golongan Habib telah mengharuskannya berdasarkan dalil serta hujah-hujah yang tertentu. Oleh itu, penulisan ini berfungsi untuk mengupas dalil-dalil yang dikemukakan oleh golongan Habib khususnya dalam mengharuskan perbuatan bertawassul dengan orang soleh yang telah meninggal dunia dan juga dalil yang mengharuskan bertawassul dengan perkataan Madadyang membawa maksud pertolongan.

\section{Metode}

Kajian ini merupakan kajian kualitatif yang mana proses pengumpulan data dilakukan melalui metode analisis kandungan terhadap karya-karya para Habib seperti Meniti Kesempurnaan oleh Habib Munzir al-Musawa, Mana Dalilmya oleh Habib Novel bin Muhammad dan Kenalilah Akidabmu juga oleh Habib Munzir al-Musawa. Selain itu, data juga diperolehi melalui sumber-sumber internet yang berautoriti seperti laman web rasmi beberapa tokoh Habib yang terkemuka dan seumpamanya. Seterusnya, proses penganalisisan data pula dilakukan dengan menggunakan metode deskriptif, tematik dan komparatif iaitu dengan menjelaskan semula data-data yang telah diperolehi. Kemudian,

\footnotetext{
${ }^{3}$ Surah Yūsuf, 12:97-98.

${ }^{4}$ Ibn Kathīr, Abī al-Fidā' Ismā̄̄īl bin 'Umar bin Kathīr, Tafsir Al-Quran Al-'Aẓm, Kedua (Riyadh: Dār Țayyibah, 1999).
} 
data-data tersebut diklafikasikan kepada beberapa tema yang tertentu seterusnya kajian turut membandingkan kefahaman para Habib terhadap dalildalil yang dikemukakan dengan kefahaman serta pendapat para ulama muktabar mengenai sesuatu isu tersebut.

\section{Bertawassul dengan Orang Soleh yang Telah Meninggal Dunia}

Ketika membincangkan mengenai keharusan bertawassul dengan orang soleh yang telah meinggal dunia, para ulama telah berselisih pendapat. Sebahagian ulama termasuk kebanyakan individu yang terdiri daripada golongan $\mathrm{Habib}^{5}$ mengharuskan perbuatan bertawassul dengan orang soleh yang telah meninggal dunia dan sebahagian yang lain pula telah melarang serta menganggapnya salah kerana tidak dilakukan oleh Nabi SAW dan para sahabat serta tabiin. ${ }^{6}$ Bagi golongan yang mengharuskan, harusnya bertawassul dengan orang soleh yang telah meninggal dunia ini sama seperti harusnya bertawassul dengan orang soleh yang masih hidup dan golongan ini telah mengemukakan beberapa hujjah. Antaranya:

1. Kemuliaan yang ada pada seseorang itu berkekalan walaupun jasadnya sudah tiada kerana kemuliaannya bukan terletak pada individu tersebut, tetapi ia merupakan sifat yang kekal. Kemuliaan yang dimaksudkan termasuklah kedudukan Nabi SAW dan kemuliaan orang-orang soleh. Ia tidak akan terhapus dengan kematian. ${ }^{7}$ Keyataan ini juga disokong oleh Musa Muhammad Ali di dalam karyanya menyatakan bahawa ramai ulama yang mengharuskan perbuatan bertawassul dengan Nabi SAW selepas kewafatan baginda dan juga orang soleh yang telah meninggal dunia. ${ }^{8}$ Sementara itu, Muhammad al-Fāqī pula menambah:

Jelas kepada kamu bahawa orang mati tetap hidup di dalam kubur mereka dan harus bertawassul dengan roh-roh baik yang telah mati dan harus meminta pertolongan atau Istighāthah dengan roh-roh tersebut sama seperti harusnya Istighāthah dengan orang yang

\footnotetext{
${ }^{5}$ Habib Munzir al-Musawa, Kenalilah Akidahmu, n.d.

6 Zakaria@Mahmod bin Daud, “Tawassul Dengan Roh Para Wali: Huraian Dan Ulasannya," Jurnal Usuluddin, 2, 4 (1996).

${ }^{7}$ Habib Munzir al-Musawa, "Kenalilah Akidahmu 2," n.d.

${ }^{8}$ Mūsā Muḥammad 'Alī, "Haqịqah Al-Tawassul Wa Al-Wasīlah 'Ala Dau' Al-Kitāb Wa AlSunnah," Al-Turath Al-'Arabi, 1981.
} 
hidup dan tidak ada beza di antara orang yang ditawassulkan itu sama ada yang masih hidup atau yang telah mati. ${ }^{9}$

2. Selain itu, Habib 'Alībin Zaynal-'Ābidīn al-Jufrîn ${ }^{-10}$ ketika ditanya di dalam laman web rasminya mengenai keharusan bertawassul dengan orang soleh yang telah meninggal dunia, beliau telah membawakan sebuah hadis yang mengisahkan perbuatan Nabi SAW sebagai bukti yang kukuh terhadap kenyataan mereka:

Diriwayatkan daripada Anas bin Mālik mengatakan ketika Fāṭimah binti Asad iaitu ibu kandung Saidina 'Ali RA meninggal dunia, baginda Nabi SAW turut sama mengebumikan jenazah Fāțimah binti Asad. Kemudian, ketika Nabi SAW membaringkan jenazahnya di dalam liang lahad, Nabi SAW telah berdoa utk Fāțimah binti Asad dengan doa berikut:

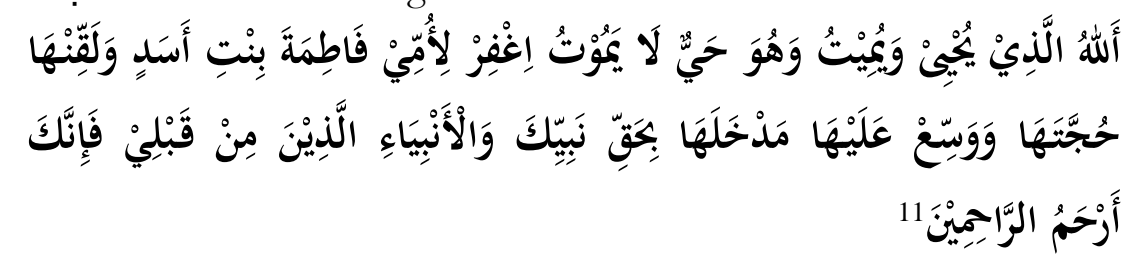

Allah yang menghidupkan dan mematikan. Allah Maba Hidup, tidak akan mati. Ampunilab ibuku, Fațimah binti Asad, ajarkanlah bujjah untuknya dan lapangkanlah kuburnya, dengan bak NabiMu dan para Nabi sebelumku. Sesunggubnya Engkaulah yang Maha Mengasibani.

Golongan yang mengharuskan termasuk para Habib menjadikan hadis doa Nabi SAW untuk Fāțimah binti Asad ini sebagai dalil yang menjelaskan bahawa Nabi SAW telah bertawassul dengan kemuliaan baginda sendiri serta kemuliaan para nabi yang terdahulu dalam doa baginda. Secara tidak langsung, perbuatan baginda SAW tersebut menunjukkan harusnya bertawassul dengan orang soleh yang telah meninggal dunia termasuk para nabi terdahulu.

\footnotetext{
${ }^{9}$ Muhammad al-Fāqī, Al-Tawassul Wa Al-Ziyārah Fi Al-Syaricah Al-Islämiyyah (Mesir: Maktabah Mustafā al-Bāb, 1968).

10 Habib Ali bin Zainal Abidin al-Jufri, “لقاء صحيفة التصوف اللإسلامي المصرية," 2012, http:/ /www.alhabibali.com/mediapress/

11 Al-Ṭabrānī, Al-Mu'jam Al-Wasiț, n.d.
} 
3. Selain itu, Habib 'Alī al-Jufrī juga membawakan sebuah lagi hadis sebagai dalil yang menguatkan hujah harusnya bertawassul dengan orang soleh yang telah meninggal dunia. ${ }^{12}$ Dalilnya:

عن عثمان حنيف: أنَّ رجلَا كَانَ يختلِلفِ إلَّى عُثمَانَ بنِ عفانَ رَضِيَ اللهُ عَنْهُ فِي حَاجَةٍ

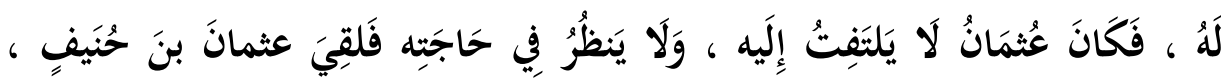

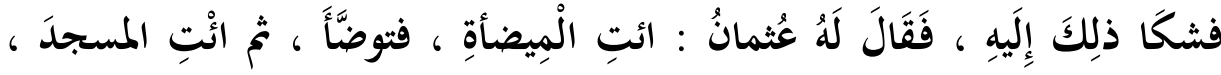

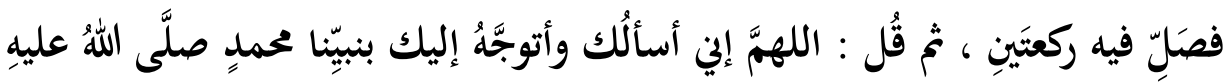

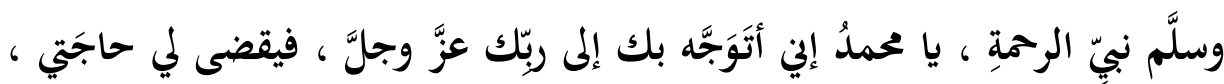

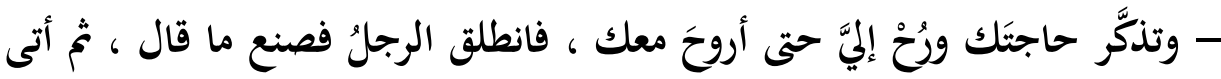
بابَ عثمانَ بنِ عفانَ رضيَ اللهُ عنه ، فجاء البوَّابُ حتى أخذ بيدِه ، فأدخلَه عليه ، فأجلَسه معه على الطُّنَسةِ ، وقال : حاجتَك ب فذكر حاجتَه ، فقضاها له ، ثم قال له : ما ذكرتُ حاجتَك حتى كانت هذه الساعةٌ ، وقال : ما كانت لك من حاجةٍ

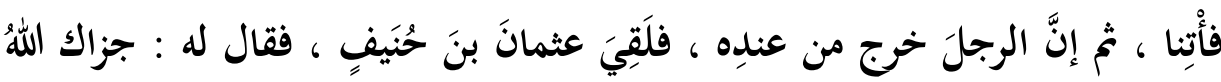

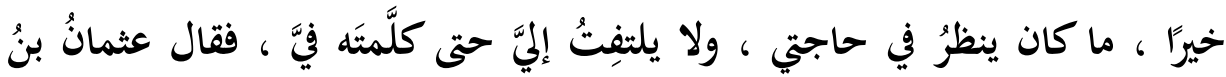

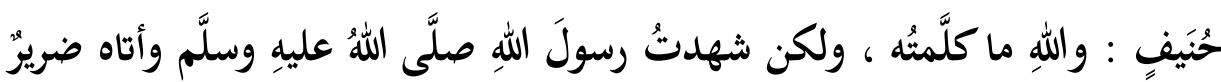

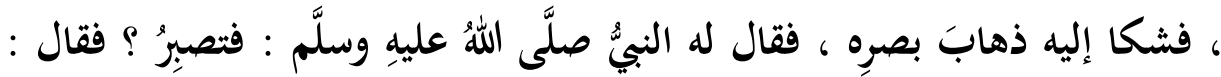
يا رسولَ اللهِ إنه ليس لي قائدٌ ، وقد شقَّ عليَّ ، فقال النبيُّ صلَّى اللهُ عليهِ وسلَّم :

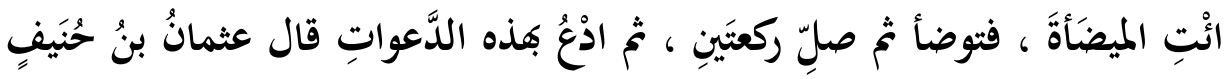

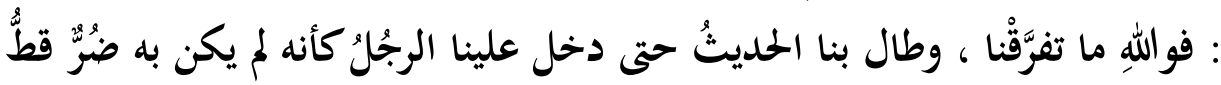

${ }^{12}$ Habib cAlī bin Zayn al-cĀbidīn al-Jufrī, لقاء صحيفة التصوف اللإسلامي المصرية/ Julai 2002,http://www.alhabibali.com/media-press/لقاء_صحيفة_التصوف_الإسلامي_المصرية/لقفية/. 
[Al-Ṭabrānī. Al-Mu’jam al-Kabīr. Bāb Mā Asnada 'Uthmān bin Ḥunayf. No. Hadis: 8311. Al-Albān̄̄. Al-Tawassul Anwāunu wa Aḥkāmuhu: 86. Kisah ini Ḍa ${ }^{\top i f f}$ Munkar]

Daripada Uthmān bin Hunayf: Seorang lelaki pernah berulang-alik kepada Uthmān bin 'Affän RA kerana sesuatu hajat untuknya. Tetapi Saydina 'Uthmän tidak menghiraukannya dan tidak melibat kepada hajatnya itu. Kemudian dia bertemu dengan Uthmān bin Hunayf, lalu mengadu kepadanya berbubung perkara itu. Maka 'Uthmàn bin Hunayf berkata: "Pergilah ke tempat wudhuk, kemudian berwudhuk, kemudian pergilah ke masjid dan kerjakan solat dua rakaat. Selepas itu berdoalah: "Ya Allah, sesunggubnya aku memohon kepada Engkau dan bertawassul kepada NabiMu Muhammad SAW, nabi yang membawa rahmat. Ya Mubammad, sesunggubnya aku bertawassul dengan engkau kepada Tubanku, maka tunaikanlah bajatku". Sebutlah hajat engkau, kemudian datanglah kepadaku sehingga aku pergi bersama kamu (menemui Saidina Uthmān). Selepas itu, dia terus pergi ke rumah Saydina 'Uthmān, kemudian datang penjaga pintu, lalu memegang tangannya dan membawanya berjumpa Saydina 'Uthmān, lalu Saydina 'Uthmän mempersilakannya duduk di atas hamparannya, dan bertanya: "Apakah hajat engkau?". Lelaki tadi memberitabu hajatnya dan kemudian hajatnya ditunaikannya oleh Saydina 'Uthmān. Kemudian Saydina "Uthmän berkata: "Aku tidak ingat hajat engkau sehinggalab ke waktu ini, sekiranya kamu mempunyai hajat lagi, datanglah menemui kami". Kemudian lelaki tadi keluar dari rumah Saydina 'Uthmän, dan terus menemui Uthmān bin Hunayf, lalu berkata kepadanya: "Semoga Allah membalas kamu dengan kebaikan, beliau tidak memberi perhatian kepada bajatku dan tidak menoleh kepadaku sehinggalah engkau mengajar aku mengenai doa tadi. Uthmān bin Hunayf berkata: Demi Allah, itu bukan daripada diriku sendiri, tetapi saya saksikan Rasulullab SAW pernab dikunjungi seorang lelaki yang buta, lalu mengadu kepadanya mengenai bilang penglihatannya. Lalu Rasulullah SAW bersabda: "Atau kamu bersabar sahaja? Lelaki tadi berkata: "Wahai rasulullah Aku tidak mempunyai seorang yang boleb memimpinku, dan itu telah menyusabkanku". Lalu Rasulullah SAW bersabda kepadanya: "Pergilab ke tempat wudbuk, kemudian berwudhuklah, kemudian kerjakan solat dua rakaat. Selepas itu berdoalah dengan doa ini. Uthmān bin Hunayf berkata lagi: Demi Allah, kami tidak berpisah dan tidak lama perbincangan kami sehinggalah lelaki tadi masuk kepada kami, seolah-olah tidak pernah buta sebelum ini" 
4. Seterusnya, sebahagian daripada golongan Habib yang mengharuskan amalan bertawassul dengan orang yang telah meninggal dunia ini juga telah menggunakan dalil 'aqli sebagai hujah untuk mengharuskan amalan ini. Mereka berpendapat bahawa tidak ada perbezaan dari segi kekuatan roh orang yang masih hidup dan orang yang sudah meninggal dunia. Malah, dibimbangi orang yang percaya hanya boleh bertawassul kepada yang hidup iaitu roh yang bersama jasad sahaja akan terjerumus kepada kemusyrikan kerana menganggap manusia yang hidup mampu memberi manfaat setanding dengan Allah SWT. Sedangkan akidah seorang muslim adalah segala yang hidup atau mati tidak mampu memberi manfaat atau mudharat kecuali dengan izin Allah. ${ }^{13}$

Pendapat ini juga disokong oleh Muhammad al-Faqi di dalam karyanya telah menulis:

"Roh seseorang apabila berpisah daripada badan ia masih lagi hidup, mendengar dan boleh berbicara sebagaimana semasa masih hidup bersama jasadnya, malah roh yang telah mati jasadnya, lebih kuat daripada roh yang masih hidup jasadnya. Mengkhususkan harus bertawassul dengan orang yang hidup sahaja tidak boleh diterima.

Oleh itu, sesiapa yang mengatakan bahawa harus bertawassul dengan orang yang hidup sahaja dan melarang bertawassul dengan orang yang telah meninggal dunia merupakan satu fahaman yang salah. Hal ini adalah kerana fahaman tersebut seolah-olah menganggap roh itu hanya berkuasa ketika jasadnya hidup dan tidak berkuasa ketika jasadnya telah mati. ${ }^{14}$

5. Kemudian, dibawakan pula sebuah analogi mudah mengenai kaedah bertawassul dengan orang yang telah meninggal dunia ini supaya masyarakat lebih faham tentang masalah ini. Analoginya seperti seorang pengemis telah datang meminta pertolongan dengan seorang raja dan memberitahu kepada raja tersebut bahawa pengemis tersebut dahulunya merupakan jiran tetangga kepada arwah isteri raja tersebut. Lantas, raja tersebut pun memberi bantuan yang banyak terhadap si pengemis. Melalui makluman tersebut, si pengemis telah mendapat manfaat yang besar

\footnotetext{
${ }^{13}$ Habib Munzir al-Musawa, Kenalilah Akidahmu.

${ }^{14}$ Wahbī Sulaymān Ghawjī, Al-Syahadatani Wa Aḥkāmubuma (Beirut: Muassasah al- Risālah, 1980).
} 
daripada orang yang telah meninggal dunia tanpa si mati itu tahu sekalipun. ${ }^{15}$

6. Pada hakikatnya, bertawassul dengan orang soleh yang telah meninggal dunia ini juga adalah seolah-olah seseorang itu bertawassul dengan amal soleh dirinya sendiri kerana amalan tawassul tersebut dilakukan atas rasa cinta terhadap Nabi SAW dan para solihin. ${ }^{16}$ Habib menerangkan bahawa dengan rasa cinta dan keyakinan bahawa orang soleh itu berada di dalam redha Allah maka tawassul tersebut dilakukan.

7. Pendapat ini juga disokong oleh Novel yang merupakan salah seorang Habib yang terkenal di Indonesia. Beliau telah mentakwilkan jika seseorang berdoa dengan lafaz "Ya Allah dengan berkat Imam Syafie perkenankanlah doaku" sebenarnya doa tersebut bermaksud "Ya Allah sesungguhnya aku mencintai Imam Syafie iaitu seseorang yang sangat cinta kepadaMu dan giat beribadah kepadaMu. Ya Allah aku yakin pula bahawa Engkau mencintai dan meredhainya. Oleh itu, dengan berkat cinta serta prasangka baik aku kepadanya, maka perkenankanlah doaku ini". ${ }^{17}$

Demikianlah antara hujah-hujah yang dikemukakan oleh golongan yang mengharuskan amalan Tawassul terhadap orang soleh yang telah meninggal dunia. Oleh itu, berdasarkan beberapa hujah yang dikemukakan, dapat disimpulkan bahawa golongan pertama ini mengharuskan perbuatan bertawassul dengan orang soleh yang telah meninggal dunia.

\section{Analisis Bertawassul dengan Orang Soleh yang Telah Meninggal Dunia}

Tidak dapat dinafikan bahawa Nabi SAW mempunyai kedudukan yang sangat tinggi di sisi Allah SWT. Namun mendakwa bahawa boleh bertawassul dengan kedudukan Nabi dan kemuliaan orang soleh kerana kedua-dua perkara tersebut merupakan perkara yang kekal walaupun jasad mereka telah tiada memerlukan kepada sandaran yang kuat. Hal ini kerana perkara tersebut termasuk antara perkara ghaib yang tidak boleh ditakwil menurut akal fikiran manusia yang terbatas.

\footnotetext{
${ }^{15}$ Habib Munzir al-Musawa, Kenalilah Akidahmu.

${ }^{16}$ Muḥammad bin 'Alwī al-Māliki, Mafähimun Yajỉ An Taṣaḥḥhh(T.Tpt: T.pt, T.th), hlm. 4445.

${ }^{17}$ Habib Novel bin Muhammad al-Aydrus, Șạh hạ Mana Dalilnya 1 (Surakarta: Taman Ilmu, 2008).
} 


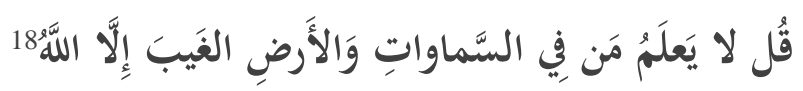

"Katakanlah: Tidak ada seorangpun di langit dan di bumi yang mengetahui perkara yang ghaib, kecuali Allah, dan mereka tidak mengetahui bila mereka akan dibangkitkan.

Salah satu hadis yang digunakan oleh sebahagian golongan Habib dalam mengharuskan amalan bertawassul dengan orang yang telah meninggal dunia iaitu hadis mengenai peristiwa yang berlaku ketika pengekebumian Fāțimah binti Asad. Di dalam hadis tersebut terdapat seorang perawi yang bernama Rūh bin Șalāh yang telah didhaifkan oleh kebanyakan ulama hadis. Antaranya Ibn 'Adī di dalam di dalam karyanya Al-Kāmil fì al-Ḍucafā' mengatakan Rūh bin Șalāh merupakan penduduk mesir dan dia seorang yang daif juga dikenali sebagai Abū al-Hārith. ${ }^{19}$ Selain itu, al-Haythamī juga memberi komentar tentang hadis ini dengan mengatakan hadis ini telah diriwayatkan oleh al-Ṭabrānī di dalam al-Mucjam al-Kabīr dan al-Mucjam al-Awsat dan di dalamnya terdapat perawi bernama Rūh bin Șalāh. Rūh bin Șalāh telah disahihkan oleh Ibn Ḥibbān dan al-Ḥākim sedangkan padanya terdapat kelemahan. Baki para perawi yang lain adalah sahih. ${ }^{20} \mathrm{Al}-\mathrm{Dā} r u q u t ̦ n \overline{1}$ pula menyatakan Rūḥ bin Salaḥ sebagai dhaif. ${ }^{21}$

Oleh kerana kebanyakkan ahli hadis telah melemahkan perawi yang bernama Rūh bin Șalah kecuali Ibn Hibbān dan al-Hākim sahaja disebabkan kedua-dua mereka terkenal sebagai Mutasabhil, ${ }^{22}$ maka perawi yang bernama Rūh bin Șalāh dianggap lemah. ${ }^{23}$ Kelemahannya lebih terbukti apabila ketika Ibn Ḥibbān mensahihkan beliau, Ibn Ḥibbān sendiri juga mengatakan bahawa Rūh bin Șalāh merupakan penduduk Mesir dan cuma meriwayatkan hadis daripada Yahyā bin Ayyūb atau penduduk Mesir sahaja. ${ }^{24}$ Namun jika dilihat kepada sanad penuh hadis di atas adalah seperti berikut:

\footnotetext{
18 Al-Quran, n.d.

19 Al-Haythamī. Nuruddin 'Ali bin Abi Bakr bin Sulaiman al-Haithami al-Misri, Majma' AlZawāìd Wa Mani' Al-Fawā’id (Beirut: Dār al-Kutub al-'Alamiyah, 2001).

${ }^{20} \mathrm{Al}$-Haythamī. Nuruddin 'Ali bin Abi Bakr bin Sulaiman al-Haithami al-Misri.

${ }^{21}$ Abū 'Abd al-Raḥmān al-Muqbil bin Hādī al-Wādīî, Tarājim Rijāl Al-Dāruquṭñ Fì Sunanibi (San'ā': Dār al-Athār, 1999).

22 Al-Sakhāwī. Muḥammad bin "Abd al-Raḥmān al-Sakhāwī., "Fatḥ Al-Mughīth Bi Shaṛ̣ Alfiah Al-Hadīth,” Rìadh: Maktabah Dār Al-Minhāj Pertama (2004).

${ }^{23}$ Abū 'Abd al-Raḥmān al-Muqbil bin Hādī al-Wādi’̄i, Tarājim Rijāl Al-Dāruquṭin Fì Sunanihi.

${ }^{24}$ Ibn Ḥibbān. Muḥammad bin Hịbbān, Al-Thiqāt, Pertama, 1973.
} 


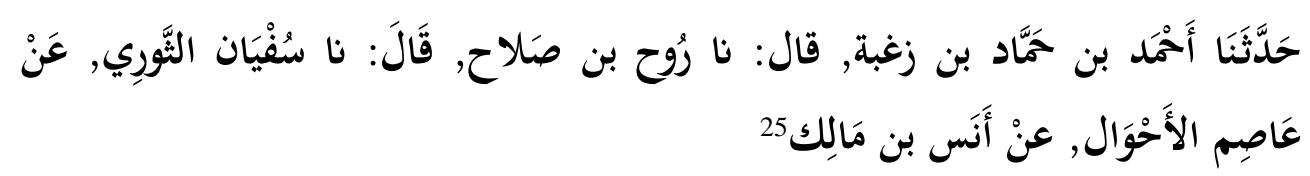

Maka, berdasarkan kepada sanad tersebut didapati bahawa Rūh bin Șalāh telah meriwayatkan hadis tersebut daripada Sufyān al-Thawrī yang merupakan penduduk Iraq. ${ }^{26}$ Oleh yang demikian, jelas bahawa Rūh bin Șalāh di dalam riwayat tersebut lemah dan bermasalah. Hal ini sekaligus telah menyebabkan hadis ini menjadi daif kerana terdapatnya seorang perawi yang daif di dalamnya sepertimana yang dinyatakan oleh Akrām Dịā' al-'Umārī. ${ }^{27}$ Selain itu, al-Albānī juga turut mendhaifkan hadis ini kerana Rūh bin Ṣalāh telah bersendirian dalam meriwayatkan hadis ini ${ }^{28}$ sekaligus menyebabkan hadis ini tidak dapat dikuatkan. Oleh itu, hadis ini tidak mampu untuk dijadikan hujah kerana ia adalah hadis dhaif.

Seterusnya, Habib 'Alī al-Jufrī juga telah berdalil dengan sebuah hadis yang mana secara ringkasnya hadis tersebut mengisahkan mengenai seorang lelaki yang ingin meminta pertolongan kepada 'Uthmān bin 'Affān RA namun 'Uthmān bin 'Affān RA tidak sempat untuk memberikan perhatian kepada lelaki tersebut. Setelah itu, lelaki tersebut berjumpa dengan 'Uthmān bin Hunayf dan ${ }^{\mathrm{c}} \mathrm{Uthmān}$ bin Hunayf telah mengajarkan doa sepertimana doa yang Nabi SAW pernah ajarkan kepada seorang lelaki buta suatu ketika dulu yang mana di dalam doa tersebut mengandungi tawassul kepada Nabi SAW walaupun ketika itu baginda telah wafat. Doa yang sama pernah diajar oleh baginda SAW kepada seorang lelaki buta yang telah dimakbulkan oleh Allah SWT doanya yang meminta agar disembuhkan butanya. Kemudian, setelah lelaki tersebut berdoa dengan doa yang diajarkan itu, Allah mentakdirkan 'Uthmān bin 'Affān melayani bahkan memberi layanan yang baik kepada lelaki tersebut.

\footnotetext{
25 Al-Ṭabrānī, Abū al-Qāsim Sulaymān bin Aḥmad al-Ṭabrānī. Al-Mu’jam al-Wasị̂,, "AlMu’jam Al-Wasiț’ empat (2014).

${ }^{26}$ Ibn Ḥajar al-'Asqalānī. Aḥmad bin 'Alī bin Ḥajar Shihāb al-Dīn al-'Asqalānī, Taqrīb Al-Tahììb (Dār al-c'Āṣimah, 2001).

${ }^{27}$ Akrām Dịā̄' al-'Umārī, Bubūth Fì Tärìkh Al-Sunnah Al-Musyarrifah (Madinah: Maktabah al'Ulūm wa al-Hikam, n.d.).

28 Al-Albānī. Muḥammad Nāṣiruddin al-Albānī, "Al-Tawassul Anwācuhu Wa Ahkāmuhu," Beirut: Al-Maktabat Al-Macārif Pertama (2001).
} 
Namun, hadis ini telah mendapat krtitikan kerana di dalamnya terdapat perawi yang bernama Syabīb bin Sa'̄d al-Makkī. Ibn Ḥajar al-'Asqalānī ketika memberi komentar mengenai Syabīb bin Sa’̄ôd al-Makkī ini menyatakan bahawa:

\section{لا بأس بحديثه من رواية ابنه احمد عنه لا من رواية ابن وهب29}

Maksud daripada kenyataan tersebut adalah Syabīb bin Sacīd ini tiada masalah jika Ibn Ahmad yang meriwayatkan daripadanya. Namun, jika Ibn Wahab yang meriwayatkan daripada beliau ia bermasalah. Kemudian, di dalam karya yang lain Ibn Hajar menyatakan jika Ibn Wahab meriwayatkan daripada Syabīb bin Sa’ìd ingatannya diragui dan Ibn Ḥajar berharap ia tidak sampai kepada tahap pendusta ${ }^{30}$ dan jika diteliti semula jalur sanad hadis tersebut adalah seperti berikut:

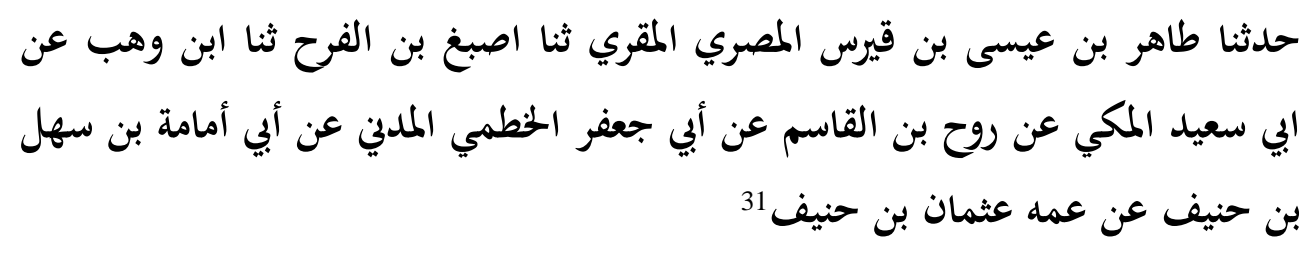

Berdasarkan kepada rantaian sanad hadis ini, kelihatan Ibn Wahab yang meriwayatkan daripada Syabīb bin Sa'īd sekaligus menjadikan riwayat ini bermasalah menurut kenyataan Ibn Hajar. Selain itu, Ibn ${ }^{\mathrm{c} A d i ̄ ~ p u l a ~ m e n y a t a k a n ~}$ bahawa jika Ibn Wahab meriwayatkan daripada Syabīb bin Sa'īd riwayat tersebut menjadi munkar. ${ }^{32}$ Oleh itu, al-Albānī menyatakan bahawa hadis mengenai Nabi SAW mengajarkan doa kepada orang buta itu sahih. Namun kisah yang diriwayatkan oleh Syabīb bin Sa'īd tentang lelaki di zaman 'Uthmān bin 'Affān tersebut daif munkar kerana lemahnya ingatan Syabīb bin Sa'īd dan riwayat ini dan telah menyelisihi riwayat lain yang diriwayatkan oleh perawi yang lebih thiqah. ${ }^{33}$

${ }^{29}$ Ibn Ḥajar al-'Asqalānī. Aḥmad bin 'Alī bin Ḥajar Shihāb al-Dīn al-'Asqalānī, Taqrīb AlTabìzib.

${ }^{30}$ Ibn Ḥajar al-'Asqalānī. Aḥmad bin 'Alī bin Ḥajar Shihāb al-Dīn al-'Asqalānī.

31 Al-Ṭabrānī, Abū al-Qāsim Sulaymān bin Aḥmad al-Ṭabrānī. Al-Mu’jam al-Wasịṭ, "AlMu’jam Al-Wasịț."

32 Al-Kāndahlawī. Muḥammad Zakariyā, Awjaž Al-Masālike Ilā Muwaț̣ā̄ Mālike, Pertama (Damsyiq: Dār al-Falāh, 2003).

${ }_{33}$ Al-Albānī. Muḥammad Nāṣiruddin al-Albānī, "Al-Tawassul Anwā̄ecuhu Wa Ahkāmuhu." 
Selain itu, Hamd 'Abd al-Majīd yang merupakan editor kitab Mu'jam alKabīr ini menyatakan bahawa tidak diragui lagi bahawa hadis tersebut merupakan hadis sahih yang marfu' daripada Nabi SAW. Namun, kisah ini diragui kerana ia menunjukkan kepada Tawaasul yang bid'ah. ${ }^{34}$ Syabīb bin Sa'īd telah bersendirian dalam riwayat ini dan beliau dinilai sebagai ' dengan dua syarat iaitu Ibn Ahmad yang meriwayatkan daripdanya dan Syabīb bin Sa'īdmeriwayatkan daripada Yūnus bin Zayd. ${ }^{35}$ Oleh kerana hadis ini lemah, bahkan sebahagian Mubaddith menghukumnya sebagai hadis munkar maka ia tidak layak untuk dijadikan hujah.

Disebabkan kedua-dua hadis yang digunakan sebagai dalil harusnya bertawassul oleh Habib 'Alī al-Jufrī ini lemah dan tidak boleh dijadikan sandaran sebagai hujah, maka adalah lebih baik diambil hadis yang sahih sebagai pengganti kepada hadis yang dhaif dalam hal ini. Sepertimana sebuah hadis yang diriwayatkan oleh al-Bukhārī di dalam sahihnya ketika berlaku kemarau pada zaman 'Umar al-Khatțāb RA, 'Umar al-Khațāāb RA telah bertawassul dengan bapa saudara Nabi SAW iaitu 'Abbās RA:

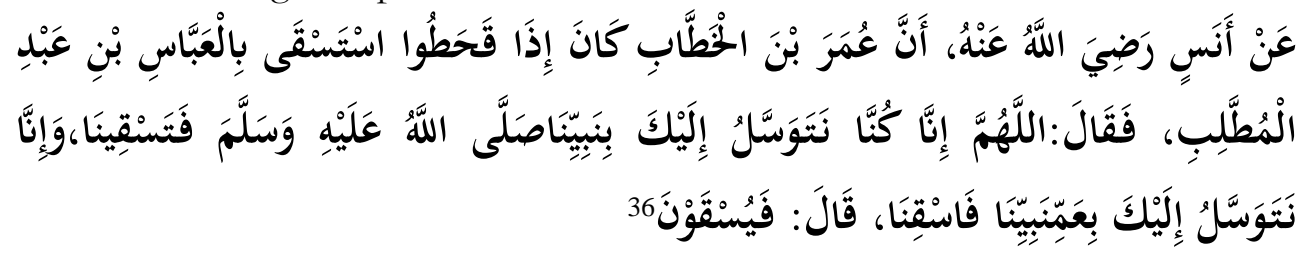

Daripada Anas $\mathrm{R} A$ meriwayatkan bahawa Umar al-Khattab $\mathrm{R} A$ apabila berlakunya kemarau, beliau bertawassul dengan 'Abbas bin 'Abdal-Mutțalib. Beliau berkata: Sesungguhnya dulu kami bertawassul kepada Mu dengan Nabi kami SAW, lalu Engkau berikan bujan kepada kami. Sesunggubnya sekarang kami bertawassul kepada Engkau dengan bapa saudara Nabi kami, maka turunkanlah bujan. Tidak. lama kemudian, bujan pun turun.

Hadis tersebut merupakan salah satu dalil yang membuktikan bahawa setelah kewafatan Nabi SAW, para sahabat tidak lagi bertawassul dengan baginda. Bahkan para sahabat bertawassul dengan orang soleh yang ada dalam

\footnotetext{
${ }^{34}$ Hamdī 'Abd al-Majīd, Al-Mucjam Al-Kabir (Qaherah: Maktabah Ibn Taymiyah, 2008).

${ }^{35}$ Hamdī cAbd al-Majīd (pnyt.), Al-Mucjam Al-Kabir (Qaherah: Maktabah Ibn Taimiyah, 2008).

36 Asqalani, Ibnu Hajar, Fatbul Baari: Penjelasan Kitab Shabih Al-Bukhari (Jakarta: Pustaka Azzam, 2006).
} 
kalangan mereka. Oleh itu, lebih baik diambil hadis sahih tersebut sebagai pengganti kepada kedua-dua hadis dhaif yang sebelum ini.

Mungkin dari satu sudut akal terlihat tidak ada perbezaan roh orang yang masih hidup dan roh orang yang telah meninggal dunia. Namun, seperti yang penulis telah nyatakan sebelum ini bahawa perkara ghaib tidak boleh ditakwil dengan akal semata-mata. Ia memerlukan kepada sandaran yang kuat kerana Allah SWT telah berfirman di dalam al-Quran:

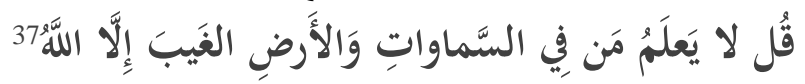

Katakanlah: "Tidak ada seorangpun di langit dan di bumi yang mengetahui perkara yang ghaib, kecuali Allab".

Ibn Kathīr rahimahullah ketika mentafsirkan ayat ini menyatakan bahawa tidak ada yang mengetahui perkara-perkara ghaib kecuali Allah SWT sahaja. ${ }^{38}$ Oleh itu, jika manusia ingin berkata-kata mengenai perkara ghaib, maka ia memerlukan kepada sandaran dalil yang kuat samada dari al-Quran, hadis atau athar. Selain itu, kenyataan bahawa roh orang yang masih hidup dan roh orang telah meninggal dunia mempunyai kekuatan yang sama tertolak dengan sendirinya atas beberapa faktor:

1. Roh ketika bersama dengan jasad mempunyai taklifan dan tuntutan agama sedangkan roh yang telah berpisah dengan jasad tidak mempunyai sebarang taklifan lagi. ${ }^{39}$

2. Roh ketika bersama jasad mempunyai pilihan dan ikhtiar yang mana mereka masih boleh berusaha untuk meraih reda Allah SWT dengan melakukan amalan-amalan yang diperintahkan olehNya. ${ }^{40}$

Oleh yang demikian, kenyataan bahawa kekuatan roh adalah sama ketika hidup dan mati tidak dapat diterima sama sekali. Malah, jika dilihat kepada sejarah awal berlakunya kesyirikan kepada Allah SWT adalah melalui ketaksuban umat Islam terhadap orang soleh yang telah meninggal dunia sepertimana yang diceritakan di dalam al-Quran mengenai kisah kaum Nabi Nūḥ AS.

Selanjutnya, bukti rasa kasih dan cinta terhadap Nabi SAW dan para solihin bukanlah dengan bertawassul kepada mereka. Bahkan bukti cinta dan

\footnotetext{
37 Al-Quran.

${ }^{38}$ Ibn Kathīr, Abī al-Fidā' Ismā̄îl bin 'Umar bin Kathīr, Tafsir Al-Quran Al-'Azim.

39 Zakaria@Mahmod bin Daud, “Tawassul Dengan Roh Para Wali: Huraian Dan Ulasannya."

40 Zakaria@Mahmod bin Daud.
} 
kasih sayang kepada Nabi SAW adalah dengan mempertahankan Sunnah baginda SAW iaitu dengan mengamalkan serta menyebarkan apa yang diajarkan oleh baginda SAW dan meninggalkan larangannya termasuklah perkara-perkara bid'ah. Perkara ini selari dengan pesanan baginda SAW buat seluruh umat Islam:

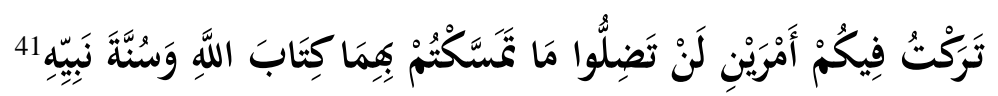
Aku telab tinggalkan kepada kamu semua dua perkara. Kamu tidak akan sesat selama berpegang kepada keduanya, (iaitu) Kitab Allab dan Sunnab RasulNya.

Hadis di atas merupakan wasiat baginda SAW supaya umat Islam berpegang teguh kepada al-Quran dan al-Sunnah. ${ }^{42}$ Selain itu, Allah SW'T juga berfirman di dalam al-Quran supaya manusia sentiasa mengikut petunjuk Nabi SAW dan berpegang teguh dengannya:

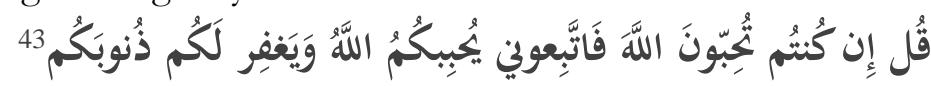

Katakanlah: "Jika kamu mencintai Allah, ikutilah aku, niscaya Allah mengasibi dan mengampuni dosa-dosamu"

Baginda SAW tidak pernah mengajarkan kepada para sahabat supaya bertawassul kepada orang yang telah meninggal dunia. Bahkan hadis-hadis yang dikemukakan juga bemasalah dan tidak layak untuk dijadikan hujah. Oleh itu, sepatutnya sebagai tanda cintakan Nabi SAW adalah dengan mengutamakan apa yang diteladani oleh baginda SAW dan bukannya mengada-adakan sesuatu yang tidak diajarkan baginda atas nama kecintaan kepada baginda SAW.

Selain itu, jika bertawassul dengan Nabi SAW setelah kewafatan baginda dibolehkan, maka timbul sebuah tanda tanya iaitu mengapa ketika para sahabat RA mengalami pelbagai masalah serta kesulitan selepas kewafatan Nabi SAW namun tidak seorang pun daripada mereka yang berdoa dengan bertawassul kepada kedudukan Nabi SAW sebagai jalan penyelesaian kepada masalah yang sedang dihadapi pada ketika itu?. ${ }^{44}$ Di samping itu, sebahagian ulama yang lain pula telah melarang perbuatan bertawassul dengan kedudukan kenabian Nabi SAW atau orang soleh yang telah meninggal dunia kerana

${ }^{41}$ Al-Kāndahlawī. Muḥammad Zakariyā, Awjaz Al-Masāilik Ilā Muwatțā’ Mālik.

${ }^{42}$ Kenan Malik, From Fatwa to Jihad: The Rushdie Affair and Its Aftermath (Brooklyn: Melville House Publishing, 2009).

43 Al-Quran.

${ }^{44}$ Al-Albānī. Muḥammad Nāṣiruddin al-Albānī, "Al-Tawassul Anwā̄euhu Wa Ahkāmuhu.” 
perkara ini tidak terdapat sandarannya daripda al-Quran. ${ }^{45}$ Sedangkan Allah SW'T telah berfirman:

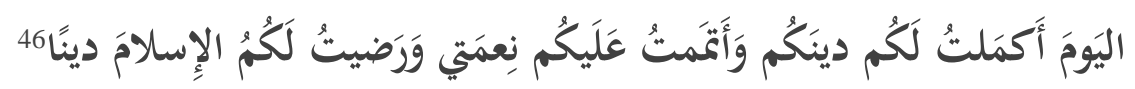

Pada hari ini telah Aku sempurnakan untuk kamu agamamu, dan telah Aku cukupkan kepadamu nikmatKu, dan telah Aku redai Islam itu jadi agama bagimu.

Bahkan tidak terdapat juga riwayat yang sahih tentang Nabi SAW atau para sahabat melakukan perkara yang sedemikian. ${ }^{47}$ Selain itu, para ulama juga melarang perkara tersebut kerana perbuatan bertawassul dengan kedudukan atau kemuliaan Nabi SAW dan orang soleh ini seolah-olah umat Islam beriktikad bahawa makhluk mempunyai kedudukan atau hak tertentu di sisi Allah yang mampu memberi manfaat serta mudarat. ${ }^{48}$ Bahkan Tawassul seperti ini mampu membuka jalan kepada kesyirikan jika berlebih-lebihan. ${ }^{49}$

Disebabkan begitu banyak keraguan yang timbul dalam hal bertawassul dengan kedudukan Nabi SAW dan kemuliaan orang soleh selepas mereka meninggal dunia ini, maka adalah lebih baik ia dijauhi untuk memilih jalan yang lebih selamat. Bahkan, menjauhinya merupakan jalan yang bertepatan dengan salah satu kaedah fiqh yang sering disebutkan oleh para ulama. Kaedahnya adalah sekiranya sesuatu amalan itu diperselisihkan hukumnya pada keharaman dan keharusan maka keluar daripada perselisihan dengan menjauhi amalan tersebut adalah lebih utama. ${ }^{50}$

Oleh itu, dapat dirumuskan bahawa dalil-dalil yang dibawa oleh golongan yang mengharuskan perbuatan bertawassul dengan orang soleh yang telah meninggal dunia termasuklah para Habib baik dalil naqli atau 'aqli kebanyakkannya lemah dan tidak relevan untuk dijadikan hujah. Bahkan terdapat begitu banyak dalil lain yang boleh dijadikan garis panduan dalam hal Tawassul ini.

Oleh itu, menjadi tanggungjawab setiap Muslim untuk memilih dalil yang sahih yang mana bertepatan dengan saranan Nabi SAW supaya umat

\footnotetext{
45 'Abdullāh bin 'Abd al-Hamīd Al-Athari, Al-Tawassul Bayna Al-Masyrù' Wa Al-Mamnü'.

46 Al-Quran.

47 'Abdullāh bin 'Abd al-Hamīd Al-Athari, Al-Tawassul Bayna Al-Masyrù' Wa Al-Mamnü'.

48"Abdullāh bin 'Abd al-Hamīd Al-Athari., Al-Tawassul al-Mashrū' wa al-Mamnū' (T.tpt: Dār Ibn Khuzaymah, T.th), hlm. 11.

${ }^{49}$ Muḥammad bin Jamīl Zīnū, "Kayfa Nafham Al-Tawassul."

${ }^{50} \mathrm{Izz}$ al-Dīn 'Abd al-'Azīz bin 'Abd al-Salām, Qawācid al-Aḥkām fi Ișlat al-Anām (Damsyiq: Dār al-Qalam, 2000), jilid. 1, hlm. 369.
} 
Islam berpegang teguh kepada al-Quran dan al-Sunnah sekaligus meninggalkan hujah-hujah yang lemah serta diragui. Kesimpulannya, tidak terdapat sandaran yang kuat baik daripada al-Quran, al-Sunnah mahupun Athar tentang amalan bertawassul dengan orang soleh yang telah meninggal dunia.

\section{Penggunaan Kalimah Madad ketika Bertawassul}

Baru-baru ini, ketika para Habib mengadakan sebuah program yang dinamakan sebagai Majlis Cinta Rasul di Malaysia, mereka telah mempersembahkan sebuah qasidah yang bertajuk al-Madad Yà Rasülulläh. ${ }^{51} \mathrm{Di}$ dalam qasidah tersebut telah diulang-ulang ungkapan al-Madad Yà Rasülulläh tersebut dan perkara itu dianggap sebagai salah satu jalan untuk mereka bertawassul dengan Nabi SAW. Namun, pada hakikatnya perbuatan sedemikian tidak lagi dikira sebagai sebahagian daripada amalan Tawassul bahkan ia telah termasuk sebahagian daripada amalan Istighäthah terhadap Nabi SAW.

Hal ini adalah kerana salah satu maksud bagi perkataanMadad atau tersebut apabila diterjemahkan ke dalam Bahasa Melayu adalah memohon pertolongan..$^{52}$ Maka, ungkapan المدد يا رسول الله maksud kami memohon pertolonganmu wahai Rasulullah dan ia merupakan satu bentuk permintaan yang jelas. Jika dikatakan Tawassul, baginda SAW sekadar menjadi perantaraan agar dikabulkan sesuatu doa, namun dalam hal ini ungkapan al-Madad tersebut merupakan permintaan secara terus kepada Nabi SAW dan itulah yang dinamakan sebagai Istighäthah. Perkara ini juga telah dijelaskan oleh Firanda Andirja Abindin, ${ }^{53}$ Mohamad Abdul Kadir bin Sahak dan Abu Anas Madani. ${ }^{54}$

Istighäthah berasal daripada perkataan Bahasa Arab iaitu استغاث yang membawa maksud meminta pertolongan untuk menghilangkan kesulitan. ${ }^{5.5}$ Antara bentuk Istighäthah adalah dengan menyeru sesuatu atau seseorang dan

\footnotetext{
52 Al-Haythamī. Nuruddin 'Ali bin Abi Bakr bin Sulaiman al-Haithami al-Misri, Majma' AlZawāid Wa Mani' Al-Fawāid.

${ }^{53}$ Firanda Andirja Abidin, Ketika Sang Habib Dikritik., 2012.

54 Abu Anas Madani, Abdul Basit bin Abdul Rahman, "Isu Madad Dan Tawassul Pencerahan Dari Abu Anas Madani,” 2014, http://www.abuanasmadani.com/isu-madad-dantawassul-pencerahan-dari-abu-anas-madani/.

55 Al-Ma'āni li Kulli Rasm Ma'na, http://www.almaany.com/ar/dict/arar/\%D $\% \% 85 \% \mathrm{D} 8 \% \mathrm{AF} \% \mathrm{D} 8 \% \mathrm{AF} /$.
} 
memohon kepadanya untuk menghilangkan kesulitan yang dihadapi. ${ }^{56}$ Secara ringkasnya, terdapat dua jenis Istighäthah yang disyariatkan di dalam Islam iaitu meminta apa-apa sahaja kepada Allah dan meminta sesuatu pertolongan kepada manusia menurut keupayaan individu tersebut dengan syarat mereka masih hidup dan ada bersama untuk mendengar permintaan tersebut. Adapun, selain daripada keduanya itu adalah termasuk dalam kategori yang dilarang antaranya meminta pertolongan kepada manusia sesuatu perkara yang berada di luar keupayaan manusia seperti meminta kepada manusia agar diampunkan dosa, dijauhkan daripada azab neraka dan seumpamanya. Ataupun meminta pertolongan kepada Nabi SAW atau orang soleh yang telah meninggal dunia kerana mereka tiada bersama untuk memenuhi hajat tersebut. ${ }^{57}$

Walaubagaimanapun, jika perkataan al-Madad tersebut dinilai sebagai Istighäthah sekalipun, ia tidak menjadi masalah di sisi para Habib. Hal ini adalah kerana ramai daripada kalangan Habib sebenarnya juga membolehkan umat Islam untuk melakukan amalan Istighäthah atau memohon pertolongan kepada orang yang telah meninggal dunia. Antara hujah yang dikemukakan bagi membolehkan perbuatan Istighäthah kepada orang yang telah meninggal dunia adalah seperti berikut:

1. Pada hakikatnya, memanggil nama seseorang untuk meminta pertolongan adalah hal yang diperbolehkan selama dia seorang Muslim, Mukmin, Soleh dan diyakini mempunyai kedudukan di sisi Allah SWT. Tidak terikat pula samada dia masih hidup atau sudah meninggal dunia kerana bila seseorang mengatakan ada perbezaan antara kehidupan dan kematian atas manfaat dan mudharat justeru dirisaukan ia berada di dalam kemusyrikan yang nyata. ${ }^{58}$

2. Kemudian, terdapat juga dalam kalangan Habib yang menyatakan bahawa Istighäthah kepada orang yang telah meninggal dunia bukanlah bermaksud meminta secara langsung kepada mereka. Namun, Istighäthah kepada orang soleh yang telah meninggal dunia itu hanyalah sebagai perantaraan. ${ }^{59}$ Analoginya ibarat manusia akan mencari doktor apabila ditimpa kesakitan namun manusia tidak menganggap doktor tersebut yang menyembuhkan

\footnotetext{
${ }^{56}$ Firanda Andirja Abindin, Ketika Sang Habib Dikritik, 2012.

${ }^{57}$ Șàlih bin 'Abd al-'Azīz bin Muḥammad bin Ibrāhīm 'Alī Syeikh, "Al-Tah mīd Li SharḥKitāb Al-Tauhīd.," Dār Al-Taubìd Pertama (2002)., Al-Tabmìd li Sharh Kitäb alTawhìd (T. Tpt: Dār al-Tawhīd, 2002), hlm. 175-179.

${ }^{58}$ Habib Munzir al-Musawa, "Kenalilah Akidahmu 2."

${ }^{59}$ Habib Munzir al-Musawa, "Meniti Kesempurnaan Iman,” 2009.
} 
penyakitnya, bahkan Allah-lah yang menyembuhkan penyakit tersebut dengan kekuasaanNya. ${ }^{60}$ Oleh yang demikian, dapat disimpulkan daripada kenyataan tersebut bahawa Istighäthah atau meminta pertolongan kepada orang telah meninggal dunia adalah dibolehkan menurut mereka.

3. Bagi menguatkan lagi hujah mengenai keharusan untuk melakukan amalan Istighäthah kepada orang yang telah meninggal dunia ini, maka didatangkan juga beberapa dalil daripada firman Allah SWT di dalam surah Yūsuf ayat ke 97 dan 98 yang menyatakan bahawa anak-anak Nabi Ya'qūb AS iaitu adik-beradik Nabi Yūsuf AS meminta Nabi Ya'qūb AS supaya beristighfar untuk mereka:

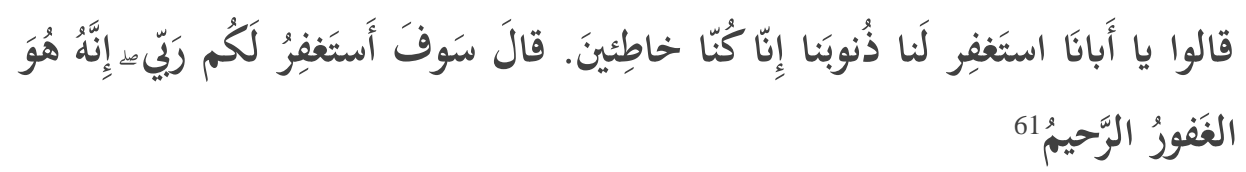

Mereka berkata: "W abai ayah kami, mohonkanlah ampun bagi kami terhadap dosadosa kami, sesunggubnya kami adalah orang-orang yang bersalah (berdosa)". Ya'qüb berkata: "Aku akan memohonkan ampun bagimu kepada Tuhanku. Sesungguhnya Dialah yang Maha Pengampun lagi Maba Penyayang".

Perbuatan tersebut dikira meminta pertolongan atau Istighäthah juga. ${ }^{62}$ Malah perbuatan tersebut telah ditiru oleh para sahabat RA yang mana terdapat dalil yang menceritakan mengenainya. Dalilnya ialah ayat alQuran daripada surah al-Nisā' ayat 64 yang mana para sahabat setelah berbuat zalim akan meminta supaya Nabi SAW beristighfar untuk mereka ${ }^{63}$ :

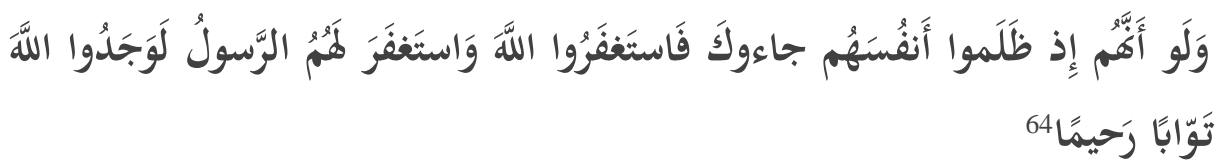

Sesunggubnya jikalau mereka ketika menganiaya dirinya datang kepadamu, lalu memohon ampun kepada Allah dan Rasul pun memohonkan ampun untuk mereka, tentulah mereka mendapati Allab Maba Penerima Taubat lagi Maha Penyayang.

\footnotetext{
${ }^{60}$ Habib Munzir al-Musawa.

61 Al-Quran.

${ }^{62}$ Habib Munzir al-Musawa, "Kenalilah Akidahmu 2."

${ }^{63}$ Habib Munzir al-Musawa.

${ }^{64}$ Al-Quran.
} 
4. Seterusnya, Habib Munzir al-Musawa juga mengaitkan kejadian Tsunami dengan hal ini. Beliau mengambil contoh ketika kejadian Tsunami yang air lautnya naik setinggi 30 meter dengan kelajuan $300 \mathrm{~km} / \mathrm{j}$ langsung tidak menyentuh salah sebuah masjid tua di Aceh dan manusia yang berlindung di masjid tersebutnya juga terselamat daripada bencana Tsunami. Inilah buktinya bahawa Istighäthah itu dikehendaki oleh Allah SWT kerana di masjid tersebut terdapatnya makam-makam para solihin. Inilah isyarat Allah memuliakan tubuh-tubuh orang yang taat kepadanya, bahkan tubuh yang tidak benyawa menjadi benteng kepada orang hidup yang berlindung di situ. ${ }^{65}$

5. Antara hujah lain yang dikemukakan lagi oleh Habib bagi mengharuskan amalan Istighäthah kepada orang yang telah meninggal dunia ini adalah berkat kesolehan kedua ibubapa anak yatim di dalam kisah pengembaraan Nabi Mūsā AS dan Nabi Khịịir AS, menjadikan harta mereka terpelihara walaupun mereka telah meninggal dunia. ${ }^{66}$

\section{Simpulan}

Berdasarkan hujah yang dikemukakan oleh para Habib tersebut seterusnya membuat kesimpulan mengenai isu ini, yaitu menyamakan kedudukan orang yang hidup dan orang yang telah meninggal dunia. Istighäthah yang diperbolehkan cuma dua jenis iaitu meminta pertolongan terus kepada Allah SWT atau meminta pertolongan kepada manusia yang masih hidup dan pertolongan tersebut mestilah sesuatu yang berada di dalam kemampuan manusia tersebut. Mustahil bagi manusia untuk meminta pertolongan kepada orang yang telah meninggal dunia. Oleh itu, secara kesimpulannya dalil-dalil yang dikemukakan oleh golongan Habib bagi mengharuskan perbuatan Istighäthah kepada orang yang telah meninggal dunia seperti mengucpkan ungkapan Madad tersebut adalah tidak bertepatan dengan kehendak dalil yang sebenar. Bahkan, dalil-dalil yang dikemukakan oleh golongan Habib telah ditafsir mengikut kehendak mereka untuk mengharuskan perbuatan Istighäthah sahaja.

\footnotetext{
${ }^{65}$ Habib Munzir al-Musawa, "Meniti Kesempurnaan Iman."

${ }^{66}$ Habib Novel bin Muhammad al-Aydrus, Sahị Mana Dalilnya 1.
} 


\section{Daftar Pustaka}

Abidin, Firanda Andirja. Ketika Sang Habib Dikritik., 2012.

Al-Albānī, Muḥammad Nāṣiruddin. Al-Tawassul Anwā'ubu Wa Abkāmubu. Beirut: Al-Maktabat Al-Ma'ārif Pertama, 2001.

'Alī, Mūsā Muḥammad. "Haqīqah Al-Tawassul Wa Al-Wasīlah 'Ala Dau' AlKitāb Wa Al-Sunnah." Al-Turath Al-Arabi, 1981.

'Alī Syeikh, Șālị̣ bin 'Abd al-'Azīz bin Muḥammad bin Ibrāhīm. Al-Tabmìd Li Sharh Kitāb Al-Taubìd. Dār Al-Tauhīd Pertama, 2002.

al-'Asqalānī, Aḥmad bin 'Alī bin Ḥajar Shihāb al-Dīn. Taqrīb Al-Tabì̄ılb. Dār al‘Āṣimah, 2001.

. Fathul Baari: Penjelasan Kitab Shabih Al-Bukhari. Jakarta: Pustaka Azzam, 2006.

Al-Athari, 'Abdullāh bin 'Abd al-Hamīd. Al-Tawassul Bayna Al-Masyrū' Wa AlMamnü, n.d.

al-Aydrus, Habib Novel bin Muhammad. Sahịh Mana Dalilnya 1. Surakarta: Taman Ilmu, 2008.

al-Bakri, Zulkifli bin Mohamad. "Ucapan Madad Ya Rasulullah," 2016. http://www.muftiwp.gov.my/index.php/ms-my/perkhidmatan-

s/irsyad fatwa/irsyad-fatwa-haji/1123-irsyad-al-fatwa-khas-haji-dankorban-siri-4 hukum-memberi-makan-daging-korban-kepada-nonmuslim.

Fāliḥ, Abū 'Abdullāh Amīr 'Abdullāh. Mu'jam Alfaz Al-'Aqìdah. Riyadh: Maktabah Al-'Abikah pertama, 1997.

al-Fāqī, Muhammad. Al-Tawassul Wa Al-Ziyāarah Fi Al-Syaricah Al-Islämiyyah. Mesir: Maktabah Mustafā al-Bāb, 1968.

Ghawjī, Wahbī Sulaymān. Al-Syahadatani Wa Ahkāmubuma. Beirut: Muassasah al- Risālah, 1980.

Al-Haythamī, Nuruddin 'Ali bin Abi Bakr bin Sulaiman al-Haithami al-Misri. Majma' Al-Zawāìd Wa Mani' Al-Fawāìd. Beirut: Dār al-Kutub al'Alamiyah, 2001.

Ibn Hiibbān, Muḥammad. Al-Thiqāt. Pertama., 1973.

Ibn Kathīr, Abī al-Fidā' Ismāîl bin 'Umar bin Kathīr. Tafsir Al-Quran Al-'Ažim. Kedua. Riyadh: Dār Ṭayyibah, 1999.

al-Jufri, Habib Ali bin Zainal Abidin. “لقاء صحيفة التصوف اللإسلامي المصرية/," 2012. http://www.alhabibali.com/mediapress/ 
Al-Kāndahlawī, Muḥammad Zakariyā. Awjaz, Al-Masālik Ilā Muwatț̣à’ Mälik. Pertama. Damsyiq: Dār al-Falāh, 2003.

Al-Ma'āni li Kulli Rasm Ma'na, n.d. http://www.almaany.com/ar/dict/arar/.

Madani, Abu Anas, Abdul Basit bin Abdul Rahman. "Isu Madad Dan Tawassul -Pencerahan Dari Abu Anas Madani," 2014. http://www.abuanasmadani.com/isu-madad-dan-tawassul-pencerahandari-abu-anas-madani/.

al-Majīd, Hamdī 'Abd. Al-Mucjam Al-Kabir. Qaherah: Maktabah Ibn Taymiyah, 2008.

- Al-Mucjam Al-Kabir. Qaherah: Maktabah Ibn Taimiyah, 2008.

Malik, Kenan. From Fatwa to Jihad: The Rushdie Affair and Its Aftermath. Brooklyn: Melville House Publishing, 2009.

Nakhuda, Mawlana Ismaeel. "Istighathah," 2009. https://www.deoband.org/2009/02/contemporary-voices/istigatha/.

al-Musawa, Habib Munzir. Kenalilah Akidahmu, n.d. . "Kenalilah Akidahmu 2," n.d.

—. "Meniti Kesempurnaan Iman," 2009.

Al-Musyarrifah, Akrām Ḍiyā' al-'Umārī. Bubūth Fī Tãrikh Al-Sunnah. Madinah: Maktabah al-'Ulūm wa al-Hikam, n.d.

Al-Quran, n.d.

Al-Sakhāwī, Muḥammad bin 'Abd al-Raḥmān al-Sakhāwī. Fatḥ Al-Mughith Bi Sharh Alfiah Al-Hadith. Riyadh: Maktabah Dār Al-Minhāj Pertama, 2004.

Al-Ṭabrānī. Al-Mu'jam Al-Wasiț, n.d.

Al-Ṭabrānī, Abū al-Qāsim Sulaymān bin Aḥmad. Al-Mu'jam al-Wasiț. n.p, 2014. al-Wādi'̄i, Abū 'Abd al-Raḥmān al-Muqbil bin Hādī. Tarājim Rijāl Al-Dāruquṭñ Fì Sunanibi. San'à': Dār al-Athār, 1999.

Zakaria, Mahmod bin Daud. "Tawassul Dengan Roh Para Wali: Huraian Dan Ulasannya." Jurnal Usuluddin, 2, 4 (1996).

Zīnū, Muḥammad bin Jamīl. Kayfa Nafham Al-Tawassul. Riyadh: Dār Al-Ṣamī'î 3 (n.d.). 